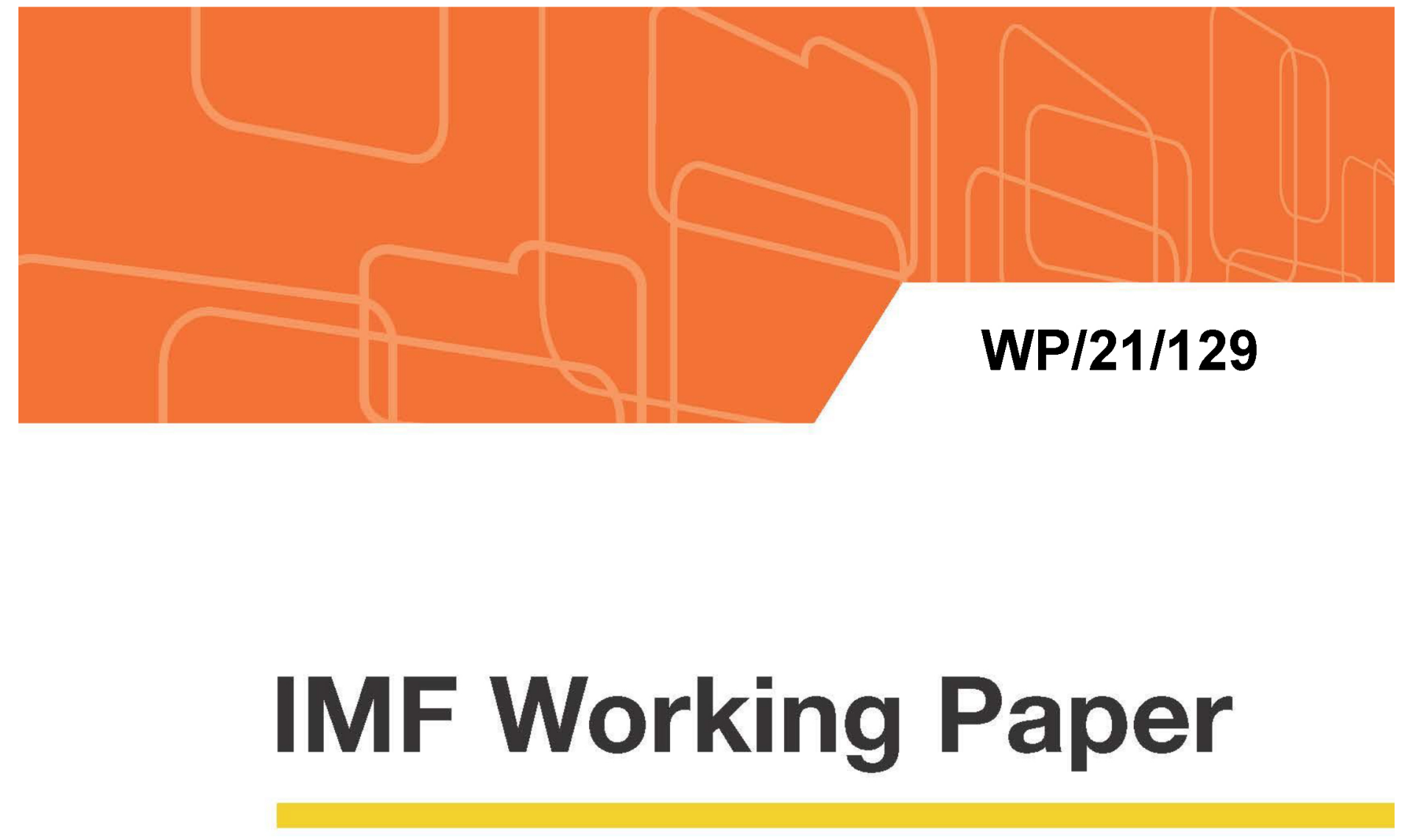

\title{
Macroeconomic Impact of the Itaipú Treaty Review for Paraguay
}

by Natasha Che

IMF Working Papers describe research in progress by the author(s) and are published to elicit comments and to encourage debate. The views expressed in IMF Working Papers are those of the author(s) and do not necessarily represent the views of the IMF, its Executive Board, or IMF management.

$$
\text { I N T E R N A T I O N A L M O N E T A R Y F U N D }
$$




\title{
IMF Working Paper
}

Western Hemisphere Department

\section{Macroeconomic Impact of the Itaipú Treaty Review for Paraguay}

\section{Prepared by Natasha Che ${ }^{1}$}

Authorized for distribution by Bas Bakker

May 2021

\section{IMF Working Papers describe research in progress by the author(s) and are published to} elicit comments and to encourage debate. The views expressed in IMF Working Papers are those of the author(s) and do not necessarily represent the views of the IMF, its Executive Board, or IMF management.

\begin{abstract}
With the debt obligation of Itaipú Binational being completed paid off by 2023, the Annex C of the Treaty of Itaipú, which governs the operation and revenue distribution of the Itaipú Dam, is due for review and possible revisions. The implications for Paraguay's export revenues and fiscal position are potentially significant. The paper reviews the current energy distribution and sales arrangements of Itaipú and the potential implication of the Annex $\mathrm{C}$ revision for the future.
\end{abstract}

JEL Classification Numbers: Q2, Q4, H6, E6

Keywords: Renewable Energy policy, Itaipú Binational, Natural Resource Management Author's E-Mail Address: NChe@imf.org

\footnotetext{
${ }^{1}$ I thank colleagues at the Central Bank of Paraguay, as well as Patricia Alonso-Gamo, Bas Bakker, and James Spalding, for their comments and suggestions. All opinions expressed are my own and do not reflect the views of the IMF, its Executive Board, or IMF management.
} 


\section{Macroeconomic Impact of the Itaipú Treaty Review for Paraguay}

\section{The Treaty OF ITAIPÚ}

The Treaty of Itaipú was signed in April 1973 for a joint investment project of hydroelectricity between Paraguay and Brazil. Discussions first began between Paraguay and Brazil in the 1960s on a possible collaboration to explore the hydro resources of the commonly shared sections of the Paraná River between the two countries, resulting in the signing of the Act of Iguaçu. After that, on April 26, 1973, the countries signed the Treaty of Itaipú, which established the joint venture Binational Itaipú, with an initial capital of USD 100 million to carry out development projects including a dam construction. The entity was constituted by ELETROBRÁS (Centrais Elétricas Brasileiras S.A. of Brazil) and ANDE (Administración Nacional de Electricidad of Paraguay). And the Treaty gave equal rights and obligations to both parties within the entity.

The construction of the Itaipú Dam started in 1975. The initial power production by the first generator unit started in May 1984. But the construction of additional units continued for more than twenty years. Currently there are twenty power generating units in the dam, with the last unit completed in 2007. Each unit has a nominal capacity of 700 megawatts (MW), which brings the total installed capacity to 14 gigawatts $(\mathrm{GW})$, second only to the Three Gorges Dam in China.

The Itaipú Dam supplies 17 percent and 90 percent of annual electricity needs of Brazil and Paraguay, respectively. Since 2007 to the present, average annual energy production of the dam has been around 94 million MWh. In 2016, the total energy production surpassed 103 million MWh, the world record of electricity produced by a single production plant.

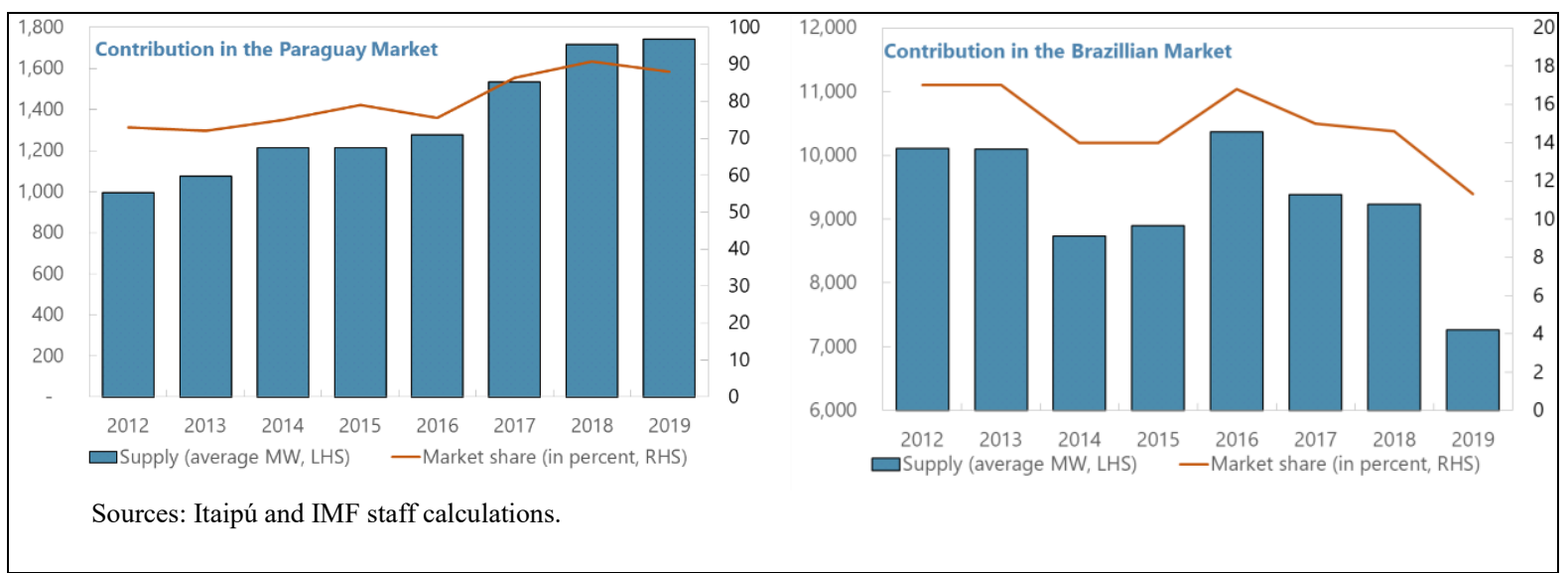


The Treaty stipulates that each country is entitled to half of the electricity generation capacity and electricity produced by the dam. ${ }^{2}$ However, if one country does not contract (i.e. purchase) all the electricity generation capacity it is entitled to, the surplus will be contracted by the other country, at near-cost prices. Lower demand for electricity in Paraguay relative to its share of energy produced by the dam, along with the

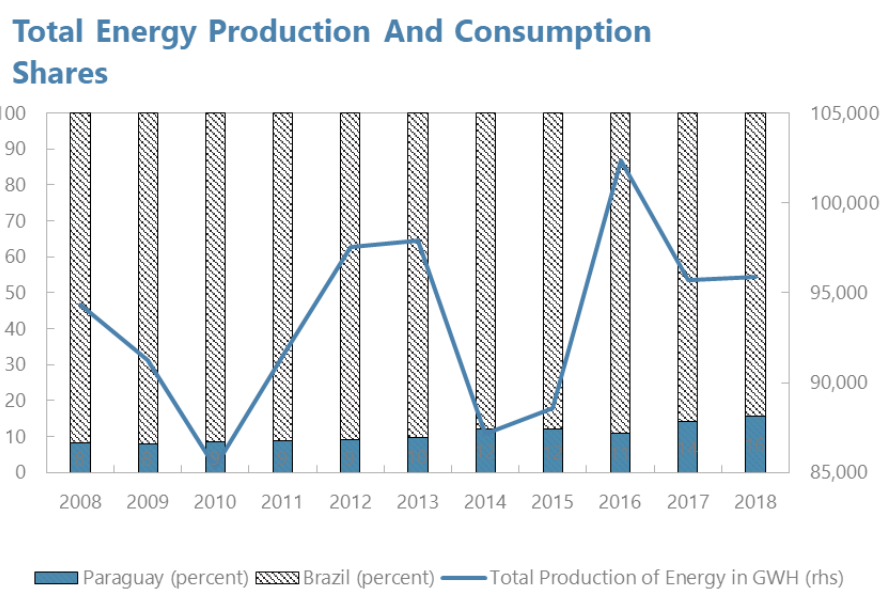

Sources: Itaipú and IMF staff calculations.

\section{Itaipú's revenues from electricity sales to Paraguay and Brazil are used for three main} purposes: 1) to service the debt incurred for building the dam, 2) to pay for operations, administration, and maintenance, and 3) to make payments to the two countries. Annex $\mathrm{C}$ of the Treaty stipulates the two main types of payments to Brazil and Paraguay, royalty payments and compensation payments. ${ }^{3}$

\section{Royalty Payments}

The royalty payments are paid to the two countries for the water used in electricity production, at a base price of USD 650 per GWh. ${ }^{4}$ The payments are then updated with an ad-hoc adjustment factor, and an adjustment factor that involves the monthly growth rates of industrial production index (IP) and consumer price index (CPI) of the United States. In other words,

$$
R_{t}=\$ 650 * E_{t} * \bar{M} * K_{t}
$$

\footnotetext{
${ }^{2}$ Electricity generation capacity is the maximum electric output an electricity generator can produce under specific conditions. Actual electricity generation may deviate from capacity. For example, if the river level is very low, electricity generation will be less.

${ }^{3}$ There is a third type of payment, the administration payment, what mainly covers the cost of operating and managing the dam. This part is relatively small and not a material source of fiscal revenues from Itaipú. Thus the discussion of the paper will focus only on royalty payments and compensation payments.

${ }^{4}$ Lorenzon et al. (2017) provides a more detailed discussion on the royalty payments and revenue distributions of Binational Itaipú.
} 
where $R_{t}$ is the royalty payment, $E_{t}$ is the energy produced, measured in GWh at time $t, \bar{M}$ is the ad-hoc adjustment factor. ${ }^{5}$ And $K_{t}$ is the adjustment factor determined by:

$$
K_{t}=1+0.5(\Delta I P)_{t} * 0.5(\Delta C P I)_{t}
$$

where $\Delta \mathrm{IP}$ and $\Delta \mathrm{CPI}$ are growth rates of the industrial production index and consumer price index of the United States.

In accordance with the Treaty, the royalties have been paid monthly to both countries since May 1985. The amount of royalties paid vary with the total energy production in each month. According to Binational Itaipú, since the first installment of royalties in 1985, the royalty payments received by the two countries have amounted to over USD 11 billion in total (around 0.9 percent and 0.02 percent of the annual average GDP for Paraguay and Brazil respectively over this period). ${ }^{6}$

\section{Compensation Payments}

The compensation payments are for the sale of electricity generation capacity that is not domestically contracted. This is in addition to the energy production cost that the purchasing party pays to Itaipú Binational. In practice, these are the payments to compensate Paraguay for the energy that it sells to Brazil. The compensation payment $\left(C_{t}\right)$ is calculated as:

$$
C_{t}=\$ 300 * E S_{t} * M_{t} * K_{t}
$$

where $E S_{t}$ is the total energy sold under the agreement, $M_{t}$ is an ad-hoc adjustment factor mutually decided by the two countries. Initially, $M_{t}$ was set to 3.5. But it has been gradually increased over time. And on September 1, 2009, the Brazilian and Paraguayan authorities signed an agreement to triple the adjustment factor starting from 2011. Table 1 provides the historical evolution of the adjustment factors. ${ }^{7}$

There is no link between both the price structure and the compensation payments and the cost of electricity from non-Itaipú sources. Since the prices of Itaipú's electricity generation capacity are cost-based, not market-based, changes in the prices of alternative energies may result in the Itaipú prices being lower or higher than alternative energy sources. For example, a sharp rise in oil prices will not lead to an increase in the compensation

\footnotetext{
${ }^{5} \bar{M}$ was initially set at 3.5 in 1985 . It has been kept at 4 since 1992 .

${ }^{6}$ See https://www.itaipu.gov.br/en/social-responsibility/royalties

${ }^{7}$ Collected from Itaipú (2018).
} 
payments, and a sharp decline in oil prices will not lead to a reduction. Several authors have argued that if such a link had existed, past compensation payments would have been higher. ${ }^{8}$

\begin{tabular}{|c|c|c|c|c|c|c|c|}
\hline \multicolumn{7}{|c|}{ Table 1. Paraguay: Historical Evolution of the Adjustment Factor } \\
\hline Year & $\left(M_{t}\right)$ & $\left(K_{t}\right)$ & $\left(M_{t} * K_{t}\right)$ & Year & $\left(M_{t}\right)$ & $\left(K_{t}\right)$ & $\left(M_{t} * K_{t}\right)$ \\
\hline $\mathbf{1 9 8 5}$ & 3.50 & NA & NA & $\mathbf{2 0 0 2}$ & 4.00 & 1.48 & 5.92 \\
\hline $\mathbf{1 9 8 6}$ & 3.50 & NA & NA & $\mathbf{2 0 0 3}$ & 4.00 & 1.53 & 6.12 \\
\hline $\mathbf{1 9 8 7}$ & 3.58 & 1.03 & 3.77 & $\mathbf{2 0 0 4}$ & 4.00 & 1.60 & 6.40 \\
\hline $\mathbf{1 9 8 8}$ & 3.66 & 1.07 & 4.00 & $\mathbf{2 0 0 5}$ & 4.00 & 1.69 & 6.76 \\
\hline $\mathbf{1 9 8 9}$ & 3.74 & 1.12 & 4.28 & $\mathbf{2 0 0 6}$ & 5.10 & 1.76 & 8.98 \\
\hline $\mathbf{1 9 9 0}$ & 3.82 & 1.17 & 4.56 & $\mathbf{2 0 0 7}$ & 5.10 & 1.82 & 9.28 \\
\hline $\mathbf{1 9 9 1}$ & 3.90 & 1.20 & 4.80 & $\mathbf{2 0 0 8}$ & 5.10 & 1.94 & 9.89 \\
\hline $\mathbf{1 9 9 2}$ & 4.00 & 1.23 & 4.92 & $\mathbf{2 0 0 9}$ & 5.10 & 1.85 & 9.44 \\
\hline $\mathbf{1 9 9 3}$ & 4.00 & 1.25 & 5.00 & $\mathbf{2 0 1 0}$ & 5.10 & 1.93 & 9.84 \\
\hline $\mathbf{1 9 9 4}$ & 4.00 & 1.28 & 5.12 & $\mathbf{2 0 1 1}$ & 15.30 & 2.04 & 31.21 \\
\hline $\mathbf{1 9 9 5}$ & 4.00 & 1.32 & 5.28 & $\mathbf{2 0 1 2}$ & 15.30 & 2.06 & 31.52 \\
\hline $\mathbf{1 9 9 6}$ & 4.00 & 1.35 & 5.40 & $\mathbf{2 0 1 3}$ & 15.30 & 2.08 & 31.82 \\
\hline $\mathbf{1 9 9 7}$ & 4.00 & 1.37 & 5.48 & $\mathbf{2 0 1 4}$ & 15.30 & 2.10 & 32.13 \\
\hline $\mathbf{1 9 9 8}$ & 4.00 & 1.37 & 5.48 & $\mathbf{2 0 1 5}$ & 15.30 & 2.03 & 31.06 \\
\hline $\mathbf{1 9 9 9}$ & 4.00 & 1.39 & 5.56 & $\mathbf{2 0 1 6}$ & 15.30 & 2.02 & 30.91 \\
\hline $\mathbf{2 0 0 0}$ & 4.00 & 1.46 & 5.84 & $\mathbf{2 0 1 7}$ & 15.30 & 2.09 & 31.98 \\
\hline $\mathbf{2 0 0 1}$ & 4.00 & 1.49 & 5.96 & $\mathbf{2 0 1 8}$ & 15.30 & 2.16 & 33.05 \\
\hline
\end{tabular}

Over the past decade, fiscal revenues from Itaipú have averaged about 1.5 percent of GDP. The share of Itaipú royalties as percent of total fiscal revenues has been declining over the years, to 3.6 percent in 2018 . The downward trend is mostly due to increases in the denominator, as the royalty payment amount has been stable over time, at an average of USD 245 million per year. On the other hand, the compensation payments had a sharp increase in 2011 due to the update in the adjustment factor discussed above. After the adjustment factor tripled, the compensation payments increased from USD 105 million in 2010 to USD 378 million two years after. Between 2012 and 2018, the average compensation payments received by Paraguay is around USD 345 million US per year (close to 1 percent of GDP). ${ }^{9}$

The revenues from Itaipú averaged 9 percent of Paraguay's total fiscal revenue over the past decade. The share has declined over the years due to the country's strong economic

\footnotetext{
${ }^{8}$ Among others, Toledano \& Maennling (2013), Folch et al. (2017) and GIH (2020) discuss how alternative price arrangements could yield different results.

${ }^{9}$ As domestic energy consumption grows, compensation payments may come down, as Paraguay uses more of is allotted power share for domestic consumption.
} 
performance that has increased the sizes of GDP and total fiscal revenues. But the importance of Itaipú revenue might increase with the upcoming review for the Annex $\mathrm{C}$ of the Treaty.

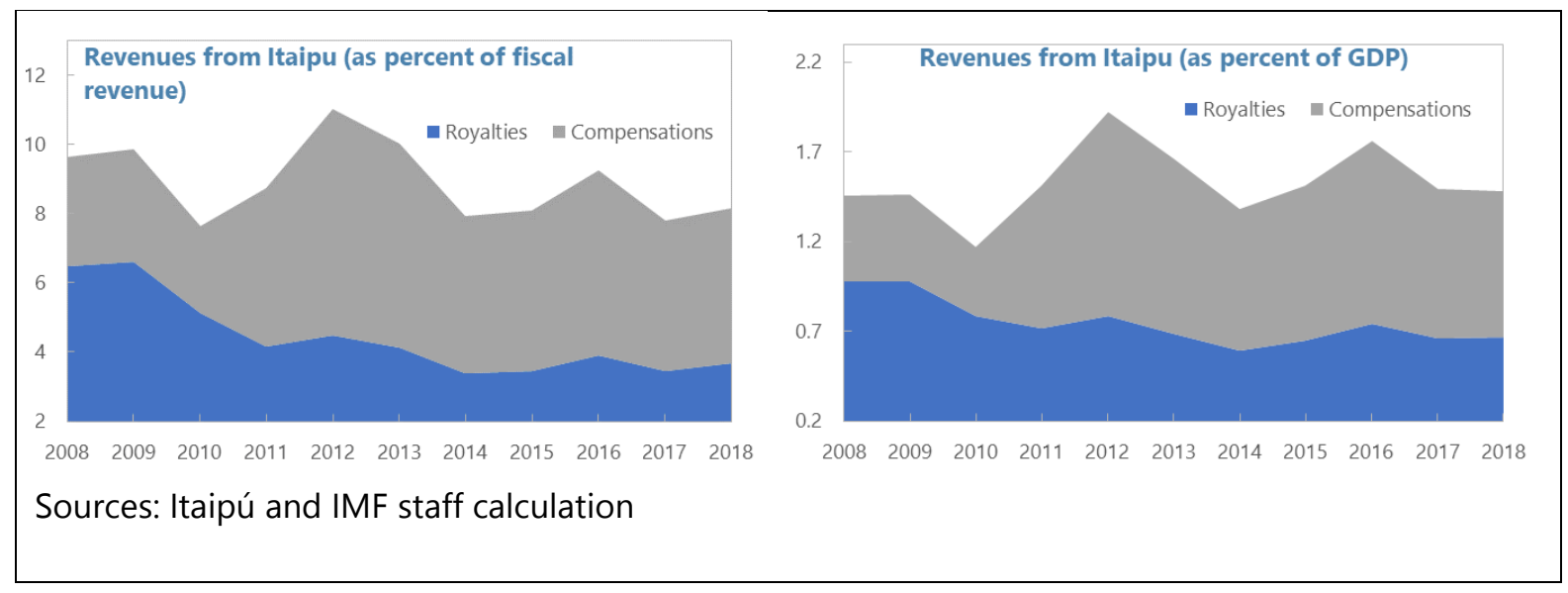

\section{MACRO IMPACT OF THE ITAIPÚ TREATY RENEGOTIATION}

Annex $C$ of the current Treaty is due for review in 2023, the year when the debt incurred by Binational Itaipú for the dam construction will be paid off. According to Itaipú (2019), the debt service and amortization cost is over 60 percent of the total service cost of Itaipú in 2019. Thus, the completion of debt services would mean that the dam would be able to operate at a much lower cost after 2023. This can have significant implications for the revenues Paraguay and Brazil receive from the dam.

\section{Several components of the Treaty can be up for negotiation in the upcoming review.}

These include, but are not limited to

a. $\quad$ the amount of royalty payments Binational Itaipú pays to Paraguay and Brazil;

b. the price of the electricity generation capacity at which Binational Itaipú sells to ELETROBRÁS and ANDE;

c. the amount of compensation payments received by Paraguay for selling its excess electricity generating capacity to Brazil;

d. whether Paraguay should be allowed to sell its excess Itaipú electricity to other countries in the region, such as Chile and Argentina, and whether it should be allowed to sell energy directly to the private sector of Brazil.

Components a) and b) are essentially about the different ways to distribute the windfall gains from Itaipú's cost reduction after 2023. Components c) and d) are about whether Paraguay should be able to earn more money from the electricity it is entitled to. 


\section{Higher Royalty Payments}

Lower costs of Itaipú after 2023 could be translated into higher royalty payments for both countries. In 2019, the debt amortization cost of Itaipú was around USD 2 billion. Assuming no other changes in the cost structure, that would lead to reduced cost / increased profit of the dam by a similar amount every year after the debt is fully paid off. If this gain were to be distributed solely as royalty payments, it would mean an additional USD 1 billion in annual payments from Itaipú to Paraguay and Brazil, i.e. more than quadruple the amount of royalty payments in 2019 . This would translate into almost 10 percent increase in Paraguay's projected fiscal revenue for 2024 (2.2 percent of projected 2024 GDP).

\section{Lower Electricity Tariffs}

The elimination of debt service cost could also be used to reduce prices at which Itaipú sells its electricity to the national electricity administrators of Paraguay and Brazil (ANDE and ELETROBRÁS). In fact, this would be the default scenario if the current terms of the Treaty do not change. Since 2009, Itaipú has been supplying its power to Paraguay and Brazil at a tariff of USD 22.6 per $\mathrm{kWm}$. The absence of the debt service cost, which constituted around 60 percent of total cost in 2019, means that, all else equal, the tariff charged by Itaipú would be lowered by a similar percentage without additional changes to the current Annex C.

The tariff reduction may benefit a wide section of the domestic economy in the long run. The quality of electricity transmission and distribution infrastructure is low compared to other countries in the region. If ANDE could keep the prices it charges to its customers unchanged, higher profits would boost the financial resources available for making the muchneeded investments in electricity infrastructure. If the cost reduction is partially passed on to end users, it will also help reduce the operational cost of the domestic productive sector. Although Paraguay currently uses less than half of its energy share of Itaipú, the tariff reduction would still amount to sizeable savings for the domestic economy, of around USD 150 million a year (0.35 percent of 2019 GDP). As the domestic industrial sector continues to grow, the cost benefit would grow larger as well. 


\section{Compensation Payments}

The treaty review can also result in higher compensation payments. Paraguay's power allotment from Itaipú has long been sold to Brazil at near-cost prices. The chart below shows the projected compensation payments as percent of fiscal revenue, if the adjustment factor were to be doubled (scenario 1) and tripled (scenario 2), from its current level.

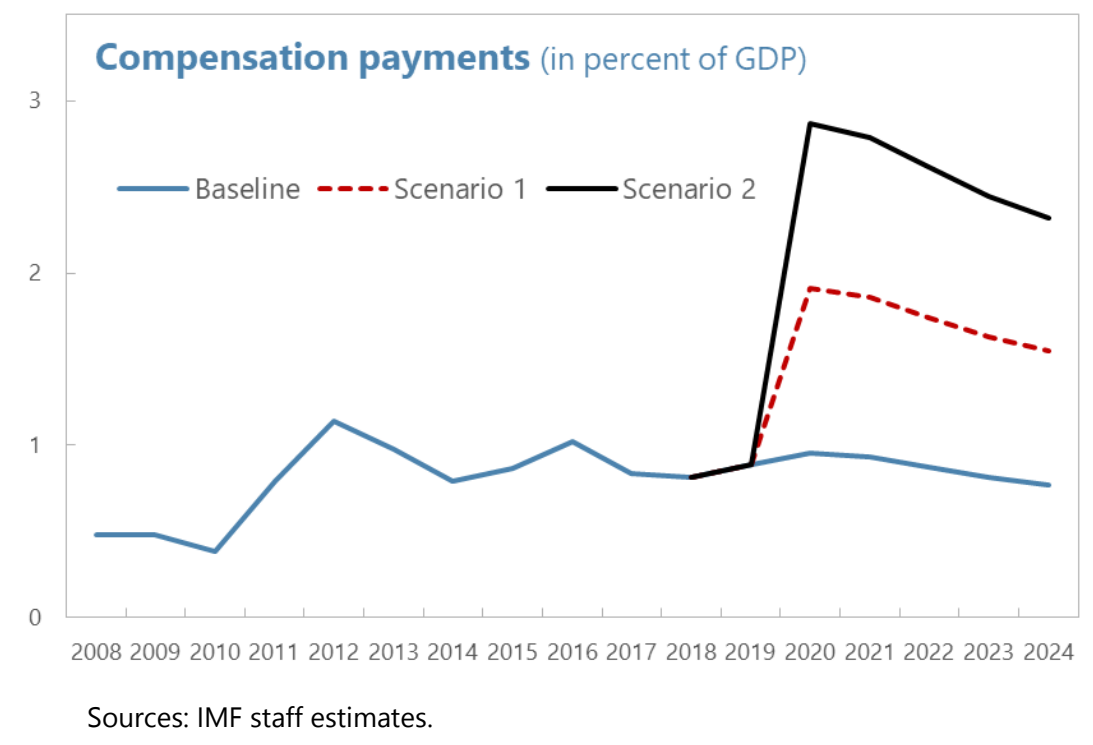

\section{Alternative Selling Arrangements}

The current exclusivity agreement, which stipulates that Paraguay's excess energy allotment from Itaipú can only be transferred to Brazil, may be also up for review. Of course, selling electricity to other countries would require examining the feasibility of other export markets and exploring alternative export partnerships. In this regard, upfront investments may be needed in the transmission and distribution infrastructure to enable alternative export arrangements.

Domestic usage of Itaipú energy resources could be expanded. Paraguay currently uses only around 40 percent of its allotted share of energy from Itaipú. And electricity export constitutes over 20 percent of Paraguay's total exports. Though directly contributing to fiscal revenues and GDP, electricity exports generate little employment and have few linkages with the domestic productive sectors. In the long run, direct energy export is a suboptimal way to take advantage of Paraguay's natural abundance in cheap electricity generation. Efforts are needed to strengthen domestic transmission and distribution networks to better use the energy resources for the development of domestic industries that produce more diversified exports and generate more domestic employment. 


\section{CONCLUSION}

The 2023 review of the Annex $C$ of Itaipú Treaty may have significant macroeconomic implications for Paraguay. The completion of the Itaipú dam's debt repayment will lead to a cost reduction for the Binational (the debt-related cost in 2019 was US\$2 billion). This can either benefit Paraguay's and Brazil's fiscal position (the gain for Paraguay could be over 2 percent of GDP, if the cost reduction of Itaipú is fully translated into increased payments to the two stakeholder countries, without any changes to the energy prices). Or it could result in a cost reduction for both domestic economies (or any linear combination of higher fiscal income and cost reduction). Passing the cost reduction directly into the domestic economy through improved energy infrastructure and reduced energy tariff could be an efficient way to distribute the gain among the population and help support private sector development. On the other hand, the revision of the Treaty can also result in changes in the agreements of compensation payments and power transfer exclusivity, which could lead to more financial gains for Paraguay in addition to the cost reduction for the Binational. Additional investments in energy transmission and distribution infrastructure are likely needed to capture Paraguay's potential in energy exports and fulfilling domestic energy needs.

\section{Windfall incomes from Itaipú should not be seen as a shortcut to solving the country's development challenges. Past researches have shown that, contrary to intuition, windfall gains from natural resources often do not improve a country's economic standing, without quality institutions and good public governance to ensure that the gains are wisely managed and spent. In the long run, exporting electricity is not an optimal way to take advantage of the country's abundant hydro resources. Sustainable growth demands a shift in Paraguay's export model, from direct energy exports to leveraging cheap energy for the development of domestic productive sectors.}

The growth impact of the Itaipú revenue will depend on how exactly the money is spent. Without additional clarity about how the revenue is going to be used, it is difficult to estimate its growth impact on the economy. If the revenue is going to be a simple add-on to the total fiscal revenue, then there is no special growth effect to speak of - the multiplier of general fiscal spending applies. The consensus in the economic literature is that expenditures in public investment generally has a higher growth multiplier than other types of fiscal expenditures. As a benchmark, the IMF Regional Economic Report (2018) for the LAC region estimated that 1 percentage point of GDP increase in public investment expenditure might lead to 0.5 percent increase in total outputs in the short term, and up to 1.5 percent cumulative increase in total outputs after 2 years. 


\section{References}

A. O. de Andrado Neto, Raiher, A. P. (2020). "An Analysis Of The Impact Of Royalties In Itaipu On The Development Of Paranaese Lindeiros Municipalities". Informe Gepec, v.24, n.2, pp. 76-96.

Carter, M. (2019). Itaipú: La Riqueza Energética Perdida de Paraguay. Available at https://static1.squarespace.com/static/5bbd787251f4d47ff1881d9b/t/5cdd58c1104c7b9d1ea3 420a/1558010073070/Miguel+Carter+-+Itaip\%C3\%BA+Causa+Nacional++ La+Riqueza+Energetica+Perdida+del+Paraguay+\%288+abril+2019\%29.pdf.

Dabán-Sánchez, T and W. Zarate, (2010). Sustainable Management of Revenues from Itaipú. IMF Country Report No. 10/170, Paraguay: Selected Issues, pp. 3-12.

Ezquerro-Canete, A. (2020). The Agrarian Question of Extractive Capital: Political Economy, Rural Change, and Peasant Struggle in 21st Century Paraguay. PhD dissertation, Saint Mary's University. SMU's Patrick Power Library repository. Available at http://library2.smu.ca/xmlui/handle/01/29476\#.YEBIUWhKhPY.

Folch, C., O. Rouvet, and O. Sanchez, (2017). Itaipú Post-2023: Strategic Investment for Paraguay's Sustainable Development. Policy brief of itaipupost2023.com. Available at https://itaipupost2023.com/itaipu-post-2023-english-language-full-policy-brief-download/.

Global Infrastructure Hub (2020). Itaipú Hydro Dam Case Study. Available at https://www.gihub.org/resources/showcase-projects/itaipu-hydroelectric-dam/.

Itaipú, (2015-2019). Financial Statements of Itaipú Binational. Itaipu Binacional. Available at https://www.itaipu.gov.br/en/company/annual-financial-statement.

Ledec, G., Quintero, J.D. (2003). Good Dams and Bad Dams: Environmental Criteria for Site Selection of Hydroelectric Projects. Latin America and Caribbean Region Sustainable Development, no. 16. World Bank, Washington, DC. World Bank. Available at https://openknowledge.worldbank.org/handle/10986/20226 License: CC BY 3.0 IGO.

Lorenzon, A. S., C.A.A.S. Ribeiro, A. R. dos Santos, G. E. Marcatti, G. F. Domingues, V. P. Soares, N. L. M de Castro, T. R. Teixeira, S. C. M. C. de Menezes, E. Silva, K. O Barros, G. M. A. D. A. dos Santos, S. F. da Silva, P. H. S. Mota, (2018). A New Methodology for Royalties Distribution of the Itaipú Hydroelectric Plant: The Hydrographic basin as the Unit of Analysis. Journal of Environment Management, v.217, n.1, pp. 710-17.

Nickson, A. (1982). "The Itaipú Hydro-Electric Project: The Paraguayan Perspective". Bulletin of Latin American Research, v. 2, n.1, 1-20.

Pappis, I., Centurion, C., Ramos, E.P., Howells, M., Ulloa, S., Ortigoza, E., GardelSotomayor, P.E., Alfstad, T. (2020). Implications To The Electricity System Of Paraguay Of 
Different Demand Scenarios And Export Prices To Brazil. Energy Systems. Available at https://doi.org/10.1007/s12667-020-00420-w.

Petersen-Perlman, J.D., Veilleux, J.C., Wolf, A.T. (2017). "International Water Conflict And Cooperation: Challenges And Opportunities”. Water International, v. 42, n. 2, pp. 105-120.

Pun, S.B. (2008). "Paraguay, Bhutan and Nepal: Landlocked but Hydropower Rich Cases of the Lame Duck, Flying Goose and Sitting Duck" Hydro Nepal: Journal of Water, Energy and Environment, n.3, pp. 4-8.

Toledano, P., \& Maennling, N. W. (2013). Report on Leveraging Paraguay's Hydropower for Sustainable Economic Development. Vale Columbia center on sustainable international investment. Available at http://ccsi.columbia.edu/files/2014/01/Leveraging-ParaguaysHydropower-for-Economic-Development-Final-CCSI.pdf.

Vuyk, C. (2019). "The Main Beneficiaries of the Transfer of Paraguayan Energy from Itaipú: Analysis of Actors And Interests for 2023". Revista Libertas, Juiz de Fora, v.19, n.2, pp. 362-386. 